\title{
Izba Pamięci i Historii wsi Frydrychowice
}

\section{Chamber of Remembrance and History of Frydrychowice Village}

Wieś Frydrychowice to malownicza miejscowość położona w województwie małopolskim, w powiecie wadowickim, w gminie Wieprz. Zamieszkuje ją około 3 tys. mieszkańców. Rozciąga się na zielonych pagórkach nad rzeką Frydrychówką z licznymi, we wgłębieniach, taflami stawów, które składają się na niepowtarzalną urodę okolicy. Na wiosnę zbocza wzniesień porastają wielobarwne kwiaty. Szczególnie dostojnie prezentują się królewskie ptaki - łabędzie, które na stałe osiedliły się na okolicznych zbiornikach wodnych.

Życie tu toczy się spokojnie, chociaż ulega ciągłej modyfikacji i ten fakt wywołał potrzebę zatrzymania się na chwilę i przeniesienia się do czasów naszych przodków, aby odpowiedzieć na pytanie: Skąd jesteśmy i dokąd zmierzamy? Na kartach historii istniejemy już prawie 700 lat. Doskonałą okazją do tego, aby pochylić się nad naszą przeszłością, była ı०o. rocznica odzyskania przez Polskę niepodległości. W całym kraju rodacy podjęli trud różnorodnych przygotowań, aby podkreślić doniosłość tego święta. W sercach i umysłach naszych mieszkańców, już kilka lat wcześniej, zrodził się pomysł utworzenia Izby Pamięci i Historii. Brakowało tylko osoby, która podjęłaby się tego przedsięwzięcia. Jako rodowita mieszkanka i wieloletnia nauczycielka pracująca w szkole podstawowej we Frydrychowicach podjęłam się tego zadania. Patronat nad utworzeniem Izby objęła Duszpasterska Rada Parafialna oraz Zespół Szkolno-Przedszkolny we Frydrychowicach. Celem utworzenia Izby było ocalenie od zapomnienia naszej przeszłości, kultury i tożsamości środowiskowej. Izba została zlokalizowana na pierwszym piętrze budynku parafialnego, w którym kiedyś odbywały się lekcje religii, a obecnie na parterze jest kaplica. Przygotowałam plan działań i projekt wykonania Izby, który został zatwierdzony przez miejscowe władze. Dzięki dużemu finansowemu wsparciu księdza proboszcza Józefa Gwiazdonia, sołtysa wsi, Dyrekcji szkoły, Rady Rodziców, Ochotniczej Straży Pożarnej i innych 
instytucji oraz osób prywatnych przystąpiono do realizacji zamierzonego przedsięwzięcia. Cały projekt nosił nazwę Ocalić od zapomnienia.

W Izbie wyodrębniono poszczególne działy, według których opracowane zostały materiały graficzne i eksponaty wystawowe. Przewodnią myślą projektu było zaproszenie zwiedzających na sentymentalny spacer po okolicy $\mathrm{z}$ wykorzystaniem starych fotografii. I tak jedna ze ścian naszego muzeum poświęcona jest parafii, kościołowi, rozwojowi religijnemu i duchowemu społeczeństwa. Kolejna ekspozycja zdjęć i pamiątek uwzględnia rozwój wsi, powstawanie organizacji społecznych oraz prezentację życia społecznego mieszkańców. Bardzo ważnym miejscem w naszej Izbie jest kącik poświęcony poległym mieszkańcom walczącym o wolność i niepodległość w czasach I i II wojny światowej oraz prześladowanym w okresie komunistycznego zniewolenia. Dużym zainteresowaniem cieszy się historia edukacji wsi, a zwłaszcza utworzona „miniklasa szkolna”.

Pierwszy pomysł utworzenia Izby dotyczył jednego pomieszczenia. Jednak ze względu na dużą ilość zgromadzonych eksponatów przekazanych

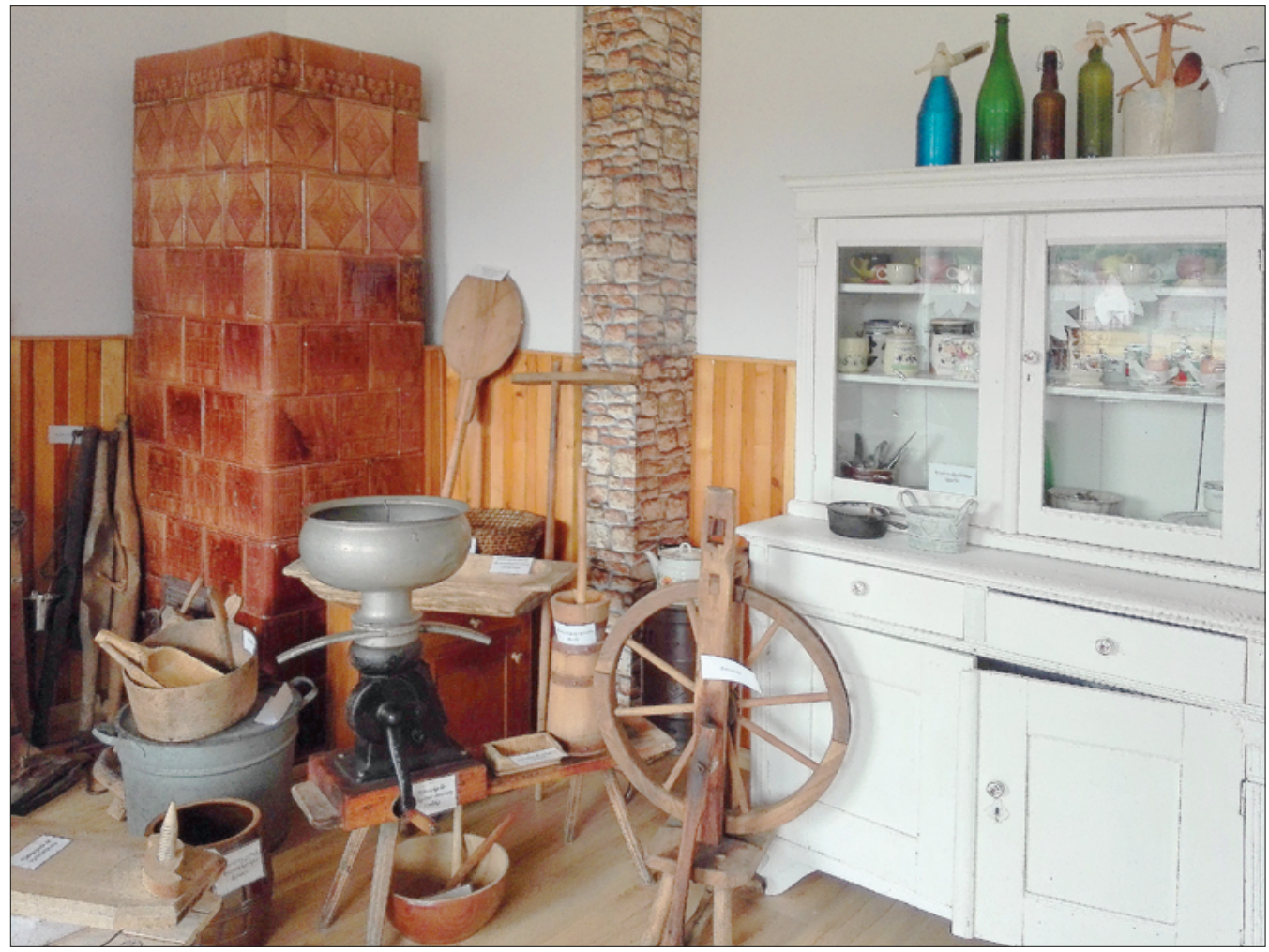

FOт. 1 Izba Pamięci i Historii Wsi Frydrychowice (fot. A. Dyrcz) 
przez mieszkańców, zrodziła się konieczność urządzenia drugiej sali, którą nazwaliśmy „sentymentalną”, gdyż w założeniu przybliża atmosferę życia codziennego naszych przodków.

Zakładając Izbę Pamięci i Historii naszej wsi, pragniemy w niej krzewić wiedzę o przeszłości, tradycjach religijnych i narodowych, przypomnieć życie naszych praojców oraz oddać hołd tym, którzy tworzyli dzieje miejscowości. Za 5 lat nasza wioska będzie świętować 700-lecie powstania. Był to dobry czas na gromadzenie pamiątek i uratowanie ostatnich okruchów wspomnień żyjących świadków historii.

Jesteśmy świadomi tego, że wychowanie patriotyczne pełniło bardzo ważną rolę w kształtowaniu postaw służących identyfikacji narodowej i kulturowej. Przygotowuje do życia w społeczeństwie. Pojęcia takie, jak niepodległość, patriotyzm, walka o wolność, tożsamość narodowa czy piękno ojczystej mowy - to dla dzieci zupełna abstrakcja. Dotyczą faktów, emocji i stanów, które dla małego dziecka są trudne do wyobrażenia. Uczniowie potrzebują konkretów: ciekawych opowieści, porównań, doświadczeń, zabaw - tego, co współgra z ich światem, co bliskie i zrozumiałe. Miłość do ojczyzny to jedno z tych uczuć, które pojawia się z czasem i potrzebuje wiedzy, świadomości, wrażliwości i refleksji. Zarówno rodzice, jak i nauczyciele powinni stworzyć dobry klimat dla rozwoju patriotycznych postaw u dzieci, aby umożliwić im poznanie wartości i norm społecznych, których źródłem jest rodzina, szkoła, społeczność lokalna i regionalna. Takim miejscem, w którym panuje dobry klimat dla wyzwalania tych postaw, jest właśnie Izba Pamięci i Historii naszej Małej Ojczyzny.

Obecnie grupy mieszkańców z zainteresowaniem odwiedzają ekspozycję umieszczoną w Izbie Pamięci, z nostalgią wspominają minione czasy. W Izbie odbywają się również żywe lekcje historii, na których uczniowie pielęgnują pamięć o dawnych dziejach. Uczą się, jak oddawać hołd tym, którzy tę historię tworzyli. Zgromadzone pamiątki, fotografie, eksponaty przenoszą ich emocjonalnie w odległy, jakże inny świat.

Uroczyste otwarcie i poświęcenie Izby nastąpiło 8 listopada 2018 r. Była to doniosła uroczystość parafialna i szkolna. Jestem dumna z tego, że w tak krótkim czasie (w okresie ı. miesięcy) przy wspólnym wysiłku wielu osób udało się zrealizować wszystkie zamierzenia.

W poczuciu odpowiedzialności poświęciłam każdą wolną chwilę, całe wakacje, aby ukończyć dzieło. Urządzanie Izby sprawiało mi tak wiele przyjemności, że przerodziło się to w pasję. Wdzięczna jestem za pomoc ludziom, którzy mi w tych działaniach towarzyszyli, obdarzyli mnie sercem, zaufaniem i wiarą w to, że sobie poradzę - nawet przy niewielkim budżecie. 
Jako twórczyni i opiekunka tego miejsca, serdecznie zapraszam do naszej Izby Pamięci. Osobiście oprowadzam zwiedzających, opowiadając o różnych ciekawych historiach, wydarzeniach i postaciach.

W czasie tworzenia Izby narodził się pomysł napisania książki Frydrychowice - nasza Mata Ojczyzna jako dopełnienie zgromadzonych fotografii, pamiątek i eksponatów. Zebrane od mieszkańców okruchy wspomnień okazały się tak cenne, że nie można ich było „włożyć do szuflady”. Niestety, sala Izby jest niewielka i nie pozwala wyeksponować historii wszystkich rodzin. Jedyne co można było zrobić, to próbować stworzyć odpowiedni klimat, aby za pomocą wyobraźni przenieść się w zamierzchłe czasy.

Książkę Frydrychowice - nasza Mata Ojczyzna oraz Izbę Pamięci i Historii potraktowaliśmy jako prezent urodzinowy dla Polski, naszej wioski, wszystkich jej mieszkańców: w hołdzie tym, co odeszli, w podziękowaniu tym, którzy tworzą jej teraźniejszość, najmłodszym - z przesłaniem o kontynuację, rozwój, dbałość i pamięć. Bowiem: „naród, który traci pamięć, przestaje być narodem - staje się jedynie zbiorem ludzi czasowo zajmujących dane terytorium" (Józef Piłsudski).

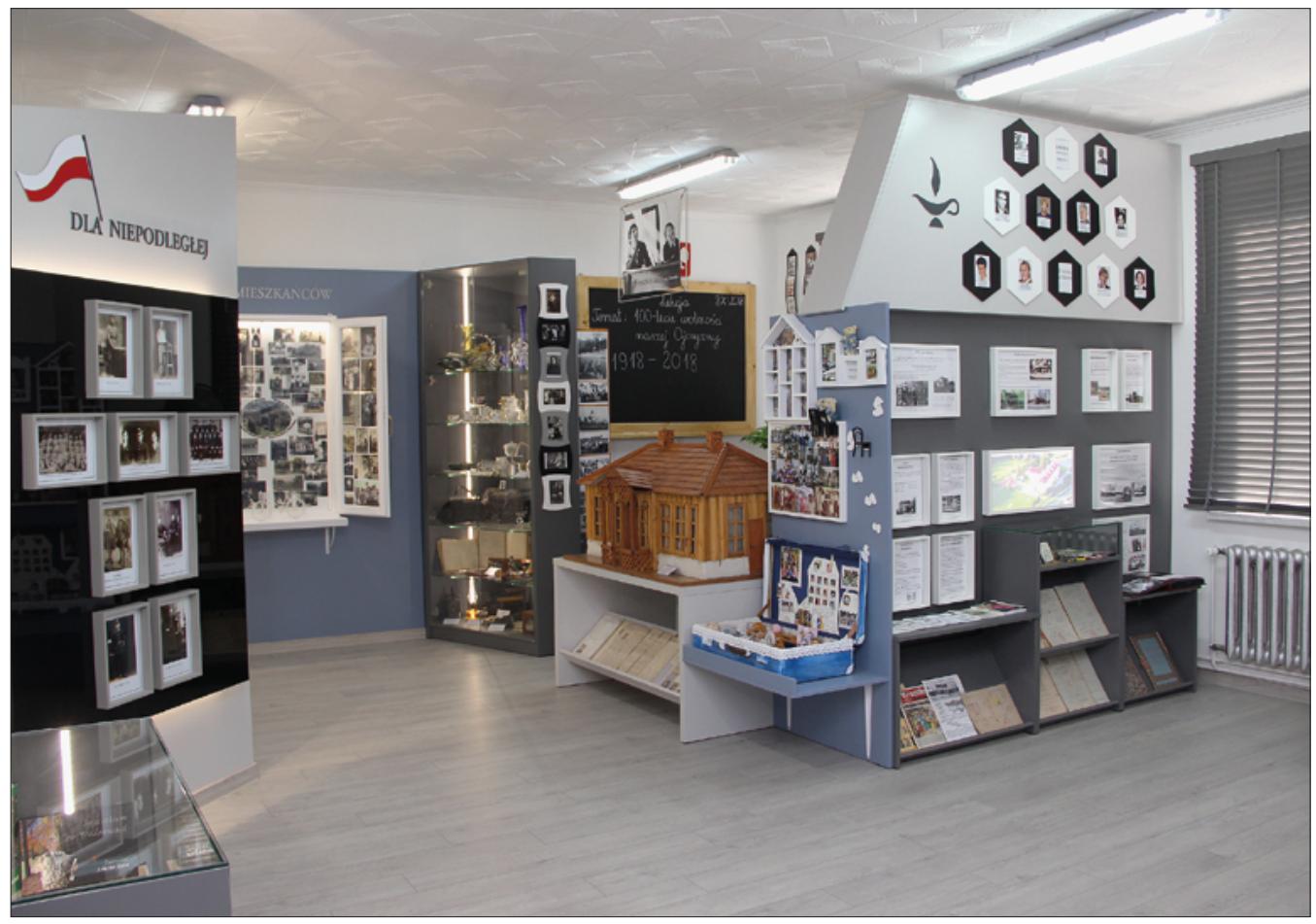

FOT. 2 Izba Pamięci i Historii Wsi Frydrychowice (fot. A. Dyrcz) 